\title{
VONDEL'S WORKS FOR THE STAGE READ AND STUDIED OVER THE CENTURIES
}

\author{
Riet Schenkeveld-van der Dussen
}

\section{Vondel and Shakespeare}

In the Netherlands Joost van den Vondel (1587-1679) is traditionally regarded as the 'prince of our poets'. The Dutch are proud of Vondel. There is a statue of him in the internationally famous (or infamous) Amsterdam Vondelpark, many streets are named after him, and he used to feature on our postage stamps as well as our pre-euro banknotes. In recommending him abroad we sometimes compare him to Shakespeare (1564-1616). They were after all contemporaries. Shakespeare died in 1616, by which time Vondel had seen his first tragedy performed (Het Pascha, Passover, 1612). They both produced a large number of plays, as well as much other writing. Shakespeare left more than forty works for the stage while Vondel wrote thirty-three. An important difference between the two men is that Shakespeare's oeuvre is more diverse, including both comedies and tragedies, some in the form of history plays, others with a fairytale character, while the majority of Vondel's work consists of biblical tragedies. In his political and historical dramas too, with a few exceptions, Christian thought is central. As a relatively young playwright and actor Shakespeare presented dramatic works on the stage with great regularity from 1590 onwards, whereas Vondel, after a hesitant start in 1610, did not begin producing his main body of work until 1637, when he was fifty. An important twentieth-century Dutch critic, Menno ter Braak, made the rather harsh observation that, as a result, 'senex' Vondel contrasted with the youthfully vibrant Shakespeare.

The reputations of both authors have had their highs and lows, but on the whole Shakespeare lives on in the theatre and in countless publications while Vondel, despite surges in attention occurring with persistent regularity, languishes. Rightly or wrongly? Either way, there is no disputing the facts. 
Despite temporary dips in his reputation, Shakespeare is alive today in the English collective memory, as demonstrated by the fact that so many lines from his work remain familiar. Innumerable book titles are quotations from the bard, from Brave New World to Pale Fire. As a result his language does not seem so old-fashioned; indeed it actually becomes richer with time as later generations add further content to it. ${ }^{1}$ Although an occasional citation of 'Waar werd oprechter trouw' ('Where was Fidelity More True') can be heard at weddings, Vondel is hardly ever quoted and so his language has missed its chance at the revitalization that Shakespeare enjoys. Still, Vondel too was a language virtuoso; more than that, he was a builder of language. Until well into the nineteenth century Dutch poetry was coloured by Vondel, even though what he wrote, certainly in his works for the stage, was almost always serious, biblical. His subject matter was serious: mankind full of guilt and shame in the presence of God. Even his lovers love each other before God's eyes: Adam and Eve in their nascent and deeply earnest happiness, or a sexually charged Urania as the ultimate sinner in the final play, Noah.

There is some truth in Ter Braak's remark. The playwright Vondel was a mature man who had left the passions of youth behind to concern himself with the great questions of human history, of state and law, good and evil, guilt and reconciliation, parent and child, fate and providence, mankind and God. What he wrote was topical at the time and indeed still is, for anyone willing to take a little trouble in reading it. In Shakespeare people act, play, joke and (also) think. With Vondel they always end up thinking. In his dramas he is never light-hearted.

\section{The Seventeenth Century}

Vondel (1587-1679) lived for almost a century and in the course of his life he increasingly became a leading figure in the Amsterdam theatrical world. It is true that his late tragedies, such as Adam in ballingschap (Adam Exiled, 1664) and Noah (1667), were not performed during his lifetime - fashions had changed - but the issuing of regular reprints of his tragedies proves they were read, admired, and indeed became the subject of dispute over many years. Controversy is surely

${ }^{1}$ For a far from complete list see http://en.wikipedia.org/wiki/List_of_titles_of _works_based_on_Shakespearean_phrases 
one of the more crucial signs of life. In his own long life he built up an impressive and extensive oeuvre of thirty-three plays, some of them translations from Seneca or Euripides but the vast majority his own work. Several of his plays were extremely successful, including Gysbreght van Aemstel (1637), specially written for the opening of the new Schouwburg, which was traditionally performed on New Year's Day and the days that followed, even well into the twentieth century, or the Joseph trilogy about the son of a shepherd who becomes viceroy of Egypt (1638-1641). The Joseph trilogy was performed, either as separate plays or as a series, a great many times until 1665. Other tragedies quickly disappeared from the stage, but Vondel's work often sparked disputes for one reason or another. Palamedes (published in 1625) was actually intended not as a play but as an allegorical indictment couched as a play, attacking Prince Maurits of Nassau and his followers for the conviction and execution of Oldenbarnevelt in 1619. It had no chance of being performed at the time; on the contrary, the published script was banned. Vondel was in danger and he escaped harsh punishment only with the help of highly placed friends in Amsterdam. He got away with a fine. Yet the play that had caused such outrage provoked responses in pamphlet form and sold extremely well for many years. On this occasion it was his political stance that had displeased those in power.

More often, his religious insights aroused opposition. To some extent this also applies to Palamedes, which Counter-Remonstrants i.e. orthodox Calvinists in particular campaigned against. It was clearly the case with the historical drama Gysbreght van Aemstel. The original intention was that one of the characters, Bishop Gozewijn, would celebrate a Mass on stage as part of the performance. That was going far too far for the Amsterdam church council and the play could not be staged until the offending passage had been scrapped. The instincts of members of the church council had in fact been rather incisive, since a short time later Vondel became a Catholic and one of the fruits of his conversion was Maria Stuart (1646), a tragedy about Mary Stuart who, as a pious Catholic in Vondel's eyes, had been executed as a martyr for the faith. It appeared in a highly volatile period. In England the Civil War had begun, ending in 1649 with the beheading of Charles I, grandson of Mary Stuart. Sympathy for the Scottish Catholic queen did not sit well in the Republic, where the Catholic Church was tolerated only as long as believers kept quiet. Exaltation of a Catholic martyr was beyond the pale. Even though he had published the play anonymously and with a 
fictional publishing house, Vondel was once again convicted and fined. The controversy led to five printings being issued in a single year. ${ }^{2}$ A few years later there were problems with Lucifer (1654), the famous drama about the rebellion and fall of the angels. Again the Calvinist clergy moved against Vondel; from the pulpit came a campaign of opposition to the portrayal of heaven and its angels in the theatre. After just two performances, pressure from the church caused Lucifer to be taken off the stage. A major part was played in all this by the Reverend Petrus Wittewrongel. In 1661 he summarized his objections to the theatre and more specifically the theatrical work of Vondel in a long passage in his Oeconomia Christiana ofte Christelicke huys-houdinghe (Oeconomia Christiana or Christian Housekeeping), in which he allies himself closely with William Prynne's celebrated and exhaustive critique of the stage Histriomastix: The Player's Scourge, or Actor's Tragedy (1632). Vondel defended himself that same year with his Tooneelschilt (Shield of the Stage). The fact that in it he presents Jesuit school drama as an example worth emulating will not have done anything to soften the clergyman's attitude.

It was not only strict Calvinists who opposed him. The Remonstrant clergyman Geeraardt Brandt, who wrote the first biography of the poet in 1682, makes it fairly plain that he held the explicitly Roman Catholic Vondel in less than high regard. Even some liberal Protestants, Andries Pels for instance, objected to religion on stage, whether because the kind of religion being propagated was 'wrong' for the Republic or because debates on stage, however well-intentioned, would only confuse simple listeners. ${ }^{3}$

In all these disputes it is noticeable that people tended simply to assert their own standpoints rather than entering into serious debates about the content of the plays. No analyses were published that set out with clarity and precision the sincere objections people had. It was more a matter of principle. In reality the church council was opposed to the theatre in general, and certainly to theatrical works by a Catholic, let alone a Catholic who put biblical subject matter on stage, thereby competing, as it were, with the only true exegetes, the Protestant clergy. Any pretext would do: a Catholic central character, a Mass, a world

\footnotetext{
2 Schuytvlot, Catalogus Vondel, nos. 282-83 (pamphlets) and 433-481(editions); Maria Stuart nos. 369-71 (pamphlets) and 633-39 (editions from 1646-1647).

${ }^{3}$ Brandt, Leven van Vondel, pp. 35-36, 38-40, 45-47; Pels, Gebruik én misbruik des tooneels, ed. Schenkeveld-van der Dussen, ll. 550-630.
} 
populated by angels. No further debate was needed. A debate would have shown, for example, that in his biblical plays Vondel was in fact presenting not an explicitly Catholic vision but rather one that was Christian in a general sense, and 'ordinary Christians' - which is what most readers and audiences in the seventeenth century were - had little difficulty with it.

The only person to make a proper analysis of a Vondel drama in order to prove an ideological point was an otherwise completely unknown woman called Meynarda Verboom. Immediately after it was published she put Adam in ballingschap under a textual microscope to demonstrate that in his tragedy Vondel had set down an unbiblical and anti-feminist vision of women. In her Pleyt voor onse eerste Moeder Eva (Plea on Behalf of Our First Mother Eve, 1664), a poem of 296 lines in pamphlet form, she contended in an astute close reading that Vondel had used a distorted, incomplete, and above all fanciful interpretation of biblical evidence to place the blame for the Fall on Eve and as far as possible to exonerate Adam.

Why, then, does Vondel feel for women such contempt?

Or does he think, perhaps, his pen will strike them dumb?

But no, the man is getting old and quarrelsome;

Whatever any woman says he'll contradict.

Since women lack both power and the kind of wit

To write a strong defence and rescue their good name,

It's perfectly all right to give them all the blame.

Make them the cause of sin, of every crime and curse;

Then man is master still, for better or for worse.

No need for Adam then to feel the least unease

Or ever blush with shame, since all the guilt is Eve's.

If that's what Moses wrote, then that's how it should be.

But he did not; it's just a poet's fantasy.

(Translation: Myra Scholz)

She explains at length why it was indeed a poet's fantasy, one for which there is no basis in the Bible. ${ }^{4}$

Aside from all these ideological objections there was in general great admiration for Vondel's artistic qualities, though towards the end of his life criticism began to be heard in this regard too, if only after initial expressions of admiration.

${ }^{4}$ Meynarda Verboom, 'Pleyt voor onse moeder Eva', Schenkeveld-van der Dussen, Met en zonder lauwerkrans pp. 305-12. See also Schenkeveld-van der Dussen in Van Gemert et al., Women's Writing from the Low Countries 1200-1875, pp. 48-49. 
Andries Pels, an advocate of French classicism, began by praising Vondel as one of the 'greatest and brightest lights of the Dutch language' - later he would call him, with heartfelt admiration, an important theoretician of drama, as demonstrated in particular by Vondel's Preface to the play Jeptha (1659) - but he went on to formulate objections to the structure of Vondel's tragedies, pointing out that they often went on for a full act after the dénouement, winding up events. He also found the circumlocutory language unsuitable for the stage. As a telling example of Vondel's dramatic poetry he quotes the first two lines of Salomon:

Thus you come far from the South, where the Cancer paints the Moors, the tree casts so little shade. ${ }^{5}$

A few decades later, attitudes to Vondel became an important matter of contention in the so-called Poets' War. Admirers rejected Frenchoriented classicism and advocated Vondel's dramatic art and poetic language as a product of their native soil and worthy of imitation. The authoritative critic Balthasar Huydecoper, himself a playwright, declared in 1730 that 'all poets nowadays have their eyes on Vondel'. Vondel's language became the prevailing 'language of Parnassus'.

The first explicatory studies to look at Vondel's political, religious, and ideological opinions, and at the stylistic structure of his work, which was gradually coming to be seen as old-fashioned, set the tone for later readers and researchers. The points made in them were returned to over many years.

\section{Eighteenth Century}

By the eighteenth century little remained of the admiration for Vondel as a writer for the theatre. The use of the word 'God' on stage was seen as objectionable and to the extent that Vondel's work was still performed at all, the scripts were expurgated. In 1729 an edition of Gysbreght van Aemstel appeared that was 'printed word for word as it is played in the Amsterdam Schouwburg', with the words God and Christ and all references to Catholic services of worship excised. It remained the standard text for years. People also criticized the structure of the

\footnotetext{
5 'Gij kwaamt dus verre van het Zuiden, daar de Kreeft / de Mooren verft, de boom zo weinig schaduw geeft.'
} 
plays. Vondel did not, for example, stick to the absolute unity of time, a requirement whereby the time taken by the action represented must coincide with the time taken by its representation, while others believed that his lengthy monologues led to one-sidedness because the character in question could not be contradicted for so long. His language was seen as uneven, with 'base' expressions occurring in elevated passages. When it came to the content, people complained that the 'love interest' was accorded too little attention. His plays were hardly ever staged, with the exception of Gysbreght van Aemstel and occasionally Faëton and Palamedes, both of which were made more attractive by the addition of spectacular 'shows'.

Although biblical tragedies were regarded as unsuitable for performance, there was a general belief that it was acceptable for them to be read. ${ }^{6}$ Yet Vondel's work rarely was. In 1720 the complete plays were issued in two volumes by the publisher Joannes van Oosterwyk as Alle de treurspelen (All the Tragedies). After that, with occasional exceptions (the Joseph trilogy, Maeghden), no new editions were published. The work nowadays seen as one of his most important, Lucifer, was not reprinted at all between 1661 and 1826. Only Gysbreght remained in print throughout the century.

Not everyone was happy about this failure to appreciate the Netherlands' most famous poet. In 1770 Le Francq van Berkhey, a poet and cultural historian, complained that 'the excellent plays of the great Vondel, Hooft [...] gems in their language, distinguished in style, are now $[\ldots]$ being supplanted by bastard hordes. But such voices had little influence. One authoritative literary theorist, Hieronymus van Alphen, did value Vondel's 'genius' and credited him as a representative of the seventeenth century, a time when literary refinement and 'good taste' had flourished in the land. He also admired his powerful and expressively emotional language. Nevertheless, in his view Vondel lacked the proper insight into aesthetic principles and as a result took liberties that detracted from 'the truly beautiful.' In any case, as a pious

${ }^{6}$ See De Haas, De wetten van het treurspel. For the text expurgated on religious grounds see pp. 204, 224; for playing time p. 98; monologues p. 144; linguistic usage pp. 18-182; love interest p. 44; biblical subject matter onstage p. 228.

For eighteenth- and nineteenth-century attitudes to Vondel see Molkenboer, Rhythme van de Vondelwaardeering; Smit 'De waardering van Vondel'; Wiskerke, De waardering voor de zeventiende-eeuwse literatuur tussen 1780 en 1813; Wiskerke, 'Wat zal ik U van onzen Vondel zeggen'; Spies, 'Nederlands vele Vondels'. 
Protestant Van Alphen will no doubt have had little respect for the Catholic Vondel.

\section{Nineteenth Century}

At the end of the eighteenth century and the beginning of the nineteenth various different notes were sounded. In reaction to the French classicism that had been dominant throughout the eighteenth century, more value was now attached to poetic originality. At the same time there was increasing admiration for the great Greek authors who had laid the foundations of European theatre, and in this context fresh admiration arose for Vondel as a representative of classical Greek theatre.

Of even greater importance than these diverse literary-theoretical opinions was a nationalistically tinted notion of progress. The seventeenth century had been a Golden Age; never had the Netherlands been so prosperous, so powerful, and so culturally rich as it was then. Of course the concept of progress brought with it the insight that even at that time perfection had not been achieved. A few years into the nineteenth century, national decline became painfully obvious: the 'Kingdom of Holland' was governed by a brother of Napoleon and thereafter became merely a part of the Napoleonic Empire, from which low point it was possible to look back for inspiration to the seventeenth century when the nation had flourished, and to express the expectation that, building upon what had been achieved in those years, a fresh start could be made, with renewed zest. Anyone who imagined progress as a spiral could combine a view of Vondel as a model with the hope of attaining a higher level. There was no need to overlook the shortcomings of his work, since they could be attributed to the more primitive cultural level of Vondel's time, but appreciation of his imaginative power, his vivid language, and especially his patriotism ought to be an inspiration - even if some dissenting voices claimed that Vondel, as a Catholic, was clearly in some respects the opposite of a useful national model.

Only a person who saw progress as purely linear rather than spiral in form would place emphasis on Vondel's shortcomings. One such person was the literary critic P.G. Witsen Geysbeek, whose views were expressed in a biographical dictionary of Dutch literary figures. He discussed the bourgeois dialogues between Sir Gijsbreght and Lady Badeloch in derisive tones and denounced the base sensuality of the 
language used by the angel in Lucifer, who falls in love with Eve. Furthermore Witsen Geysbeek views Vondel with contempt as a Catholic perpetuator of the 'Medieval Dark Ages'.

Another important factor was the emancipation of the Catholic segment of the population, which had been achieved in full at the time of the Batavian Republic (1795-1806). To this sizeable slice of the Dutch nation Vondel had now become a great hero. In their eyes Vondel's Catholicism was not something to be glossed over wherever possible. On the contrary, his conversion was an event of central importance. Only then had he found his true calling, only after he became a Catholic had his series of biblical tragedies grown to its full stature, only then had he written those wonderful apologetic didactic poems about the Eucharist, Altaergeheimenissen (Secrets of the Altar, 1645) and Bespiegelingen van Godt en Godtsdienst (Reflections upon God and Religion, 1662). It was the Catholics who introduced Vondel as a champion of the Counter-Reformation and a great baroque poet, presenting him as the literary counterpart to Rubens. ${ }^{8}$

Such debates and differences of opinion prompted responses from the academic world. The first professorships of national history and literature had been established, and their occupants pointed out that poets from the past could not be talked about as if they were contemporaries. The necessary knowledge of seventeenth-century language and culture was lacking, so it was not possible simply to praise or condemn Vondel's linguistic usage and representation of things. Professor B. Lulofs (among others) argued that much study would have to be done first. Commentaries on Vondel's work were needed and in 1831 he set an example by publishing an anthology that included notes and an introduction providing the historical background.

Catholics were particularly industrious in producing editions of the texts with accompanying commentary. They felt a need to make Vondel's work accessible to fellow Catholics. A lawyer called Hoppenbrouwers, for example, produced an edition of Altaergeheimenissen (Secrets of the Altar, 1822-1825) and the Catholic professor J.M. Schrant, who lectured on Vondel in Ghent and Leiden, was responsible for new editions of plays including Gysbreght van Aemstel (in 1851) and Lucifer (1856).

\footnotetext{
${ }^{8}$ Anton van Duinkerken, 'De Roomse Vondelschool'.
} 
It was not a Catholic, however, but a liberal who, as an admirer of the great seventeenth-century poet, was the first to set in train a weighty chronologically arranged multivolume edition of Vondel's complete works, editing and partly financing it himself. His name was Jacob van Lennep and he had been a devotee of Vondel since childhood; he knew Gysbreght by heart by the time he was six, having been mesmerized by a New Year's Eve performance of the play. Between 1855 and 1869 twelve volumes appeared, dedicated to King William III. It firmly established Vondel as a national poet for all Dutch people. To make it more attractive Van Lennep had his edition illustrated by contemporary artists. Events in Vondel's life were depicted, and illustrations were included in the works themselves. Seventeenth-century plates were replaced with nineteenth-century versions, for which Van Lennep was later much criticized.

But Van Lennep wanted above all to produce a scholarly edition. He put a great deal of work into elucidating the text, dating the poetry, unearthing biographical details, and exploring the political and religious context of the poems. The resulting scholarship was made accessible by means of extensive indexes that have retained their usefulness to this day.

Van Lennep's work gave an impetus to further editions of Vondel's texts, which appeared relatively soon afterwards. The freethinker Johannes van Vloten produced an edition in modern Dutch spelling in 1864-1866 that was intended to make Vondel accessible to a broader readership, and the leading Catholic J.A. Alberdingk Thijm initiated an edition with Catholic commentary that was completed by others after his death and published in 1887 . Vondel was truly a poet for everyone. It was also the time of the great Vondel festivals. In 1867 a statue of him by Royer was erected in Amsterdam. The Catholic architect Pierre Cuypers designed the plinth for the statue as well as the floats that paraded through the city as part of the festivities surrounding its unveiling. 1879 saw the celebration of the two hundredth anniversary of the poet's death.

\section{The Roman Catholic Vondel School}

Vondel editor Alberdingk Thijm is regarded as the founder of the 'Roman Catholic Vondel school.' He was the editor of a new edition of Vondel's work and he had published a generally well-received series of 
'portraits' of Vondel. Moreover, he regularly produced critical reviews in response to the work of Van Lennep. In putting together his own edition he was supported by J.F.M. Sterck, who in turn became a leading Vondelian and in 1901 the founder of the Vondel Society, which published a periodical called Vondel-Museum to which Sterck made frequent contributions of an archival or bibliographical nature. The first Catholic Vondelians produced their theses in about 1910: Moller, Brom, Molkenboer - they would all write about Vondel and edit editions of his work for decades to come. In 1933 a Chair in Vondel Studies was established at Nijmegen Catholic University and Molkenboer was the first to occupy it. To mark the occasion he gave an inaugural oration called Het rhythme van de Vondelwaardeering (The Rhythm of Vondel Appreciation), which was written mainly from a Catholic perspective. 1930 had seen the first issue of the Vondelkroniek, again at the instigation of Sterck, with Molkenboer as editor-in-chief. The journal remained in existence until 1941.

The veneration of Vondel reached one final highpoint in this period, the Commemoration of 1937, celebrated at a solemn meeting in Amsterdam, with a Gedenkboek (Commemorative Book) as a permanent contribution. That year also saw the publication of the final volume of an edition begun in 1927, De werken van Vondel. Volledige en geillustreerde tekstuitgave in tien deelen (The Works of Vondel. Complete and Illustrated Edition of the Texts in Ten Volumes). The series editor was J.F.M. Sterck and it was largely the work of Catholic scholars, including Molkenboer and the philologist L.C. Michels, but since this was after all a national publication, scholars from other denominations worked on it as well. It remains to this day the most recent scholarly edition of the complete works. In the same year, 1937, Albert Verwey, man of letters and a professor at Leiden University, issued an edition of Vondel in modern spelling, this time as a single volume and aimed at a wide, culturally engaged readership.

\section{Vondel in Modern Research}

After the Second World War, interest in Vondel among a broad audience became, frankly, a thing of the past. Even the annual tradition of performing Gysbreght van Aemstel to see in the New Year was abandoned in 1968. There is no longer a place for Vondel in Dutch secondary schools. 
The debate about his work that began in the seventeenth century belongs to the past as well. The issues that dominated discussion of Vondel for several centuries seem to have lost all relevance. Vondel's ideology leaves readers and audiences cold. The question as to whether and to what extent his work should be interpreted as Catholic excites no one any longer. His language is perceived as alienating, even curious, and hardly anyone nowadays can detect the supposed contrast between elevated and earthy tones in his work. The long speeches in his plays no longer cause irritation for their alleged one-sidedness, they merely put audiences to sleep. In short, none of the things that once angered people and led to fierce debates arouse any interest today, even in a negative sense.

Vondelian academic research quickly revived, however, and for a time it flourished once more. The customary philological method remained in vogue, as evidenced by innumerable studies and editions of the works. It would be impossible to discuss or even to name all these modern studies in this very short essay, even were we to limit ourselves to theatrical research. ${ }^{9}$ There is space only for a few examples of books that make innovative contributions. The 1950 dissertation by philosopher and literary theorist J.G. Bomhoff, for instance, influenced by the then prevalent philosophy of existentialism, attempts to understand Vondel through the prism of 'the tragic' as a universal and eternally valid category. Taking a rather different approach, Norwegian expert on German and Dutch literature Kåre Langvik-Johannessen tried in several studies between 1963 and 1987 to offer what he called a 'psychosymbolic' interpretation of Vondel's tragedy as expressing the antinomy between heaven and earth, spirit and matter, and thereby to present him as a typical baroque poet. He often interprets the characters in the tragedies as symbols for inner conflicts in the protagonist, between for example his objective-earthly and subjective-earthly selves. American professor of German studies James A. Parente studied neoclassical tragedy, including works by Vondel, in terms of its relationship to older, Christian-Humanist drama (1987). Peter King compiled word indexes and frequency lists for several works by Vondel, including Lucifer, and based on his interesting semantic investigations concluded that, from a dogmatic point of view, Lucifer is 'a failed

${ }^{9}$ For a thorough discussion of works on Vondel from 1945 to 1987 see Spies, 'Vondel in veelvoud'. 
theological play'. Incidentally, these studies indicate that Vondel had his enthusiasts and admirers, some with critical comments to make as well, even beyond the Dutch-language area. Several of his plays have appeared in translation in various European languages..$^{10}$ Lieven Rens, whose doctoral thesis took the form of a study on the narrowly focussed theme of the priest-king conflict in Vondel's tragedies, took the first step towards a psychoanalytical interpretation of Vondel's dramas in 1979. None of these approaches has as yet been taken further to any great degree.

Particularly influential, on the other hand, has been the approach of Utrecht professor of Dutch language and literature W.A.P. Smit. Between 1955 and 1962 he published a three-volume work called Van Pascha tot Noah (From Pascha to Noah) in which he treats the tragedies in chronological order, tracing the development of Vondel's poetics. Having started out as a member of a chamber of rhetoric, Vondel later encountered Seneca and translated works including Troades and Phaedra. Then he got to know Sophocles and translated Elektra. He also seems to have followed closely the literary theories of his contemporaries Hugo Grotius and Daniel Heinsius. All this led him to new Aristotelian insights: the character of the protagonist lies in the tension between good and evil, and key moments in the tragedy are the agnitio, or sudden insight into the true situation, and the accompanying reversal of events, the peripeteia. At this point something develops that Smit calls the duality drama, in which the central character himself is at stake. Smit believes Vondel's work is lent its significance by the idea of 'the meaningfulness of God's rule.' This is strongly reminiscent of Milton's 'to justify the ways of God to men', the stated purpose of Paradise Lost (1667) (I, 26). Yet the difference in emphasis should not be overlooked. In Vondel's view God does not need to be 'justified' to men; his intention is to demonstrate God's just and merciful rule.

Each volume of the study closes with an 'overview' in which the defining characteristics of the tragedy under discussion are set out schematically, a didactic aid that made the book significantly more persuasive.

${ }^{10}$ For example, English versions of Gysbrecht van Aemstel (1991) and Mary Stuart, or Tortured Majesty (1996) by Kristiaan Aercke and of Lucifer by Charles van Noppen (1898 repr. 1942) and Noel Clark (1990). 
Smit's book, with its strongly historicizing approach, combined with 'close reading' as he himself remarks, was in a positive sense a milestone and in a negative sense almost a terminus. There seemed to be hardly any room left for alternative readings, all the more so since Smit, from his principles based on contemporary insights, also seriously and powerfully contested the studies produced before and after his own. Bomhoff's opinions were in his view 'typically modern' and took no account of Vondel's beliefs or his sources. J. Poulssen suggested in 1963 that the all-pervasive influence of seventeenth-century literary theory which Smit describes may have amounted to an obstacle to Vondel, perhaps adversely affecting his 'poetic identity'. Smit claimed that this argument had largely remained stuck at the hypothetical stage. ${ }^{11}$

Smit's approach fits neatly into the literary-historical paradigm in force in his own day, with its focus on seventeenth-century rhetoric and the literary theory of the author's time. The same foundations were built upon for many years. Other interesting and innovative studies on Vondel's dramas appeared, theoretically following in Smit's footsteps, along with editions of the works that continued to build upon his insights. The chorus was studied by Lia van Gemert (1990). Jan Konst wrote his 1993 dissertation on the passions in seventeenth-century tragedy, paying much attention to Vondel, and in his Fortuna, fatum en providentia Dei in de Nederlandse tragedie (Fortuna, Fatum, and Providentia Dei in Dutch Tragedy, 2003) he devotes the entire second volume of some 125 pages to Vondel. Points of departure are formed by the ideas of Vondel's day about the passions and about the broad issue of fatum (fate) and divine dispensation.

To get out from under the shadow of Smit's book a paradigm shift was required, a switching of attention from the literary historian to the reader, the self-determining reader, the deconstructing reader. In his detailed responses to positions taken by others, Smit noted that their interpretations were too modern or too hypothetical, but such arguments were no longer regarded as valid. Readers refused to be governed by seventeenth-century literary theories. Poulssen had already put forward the hypothesis that Vondel had perhaps allowed himself to be overly browbeaten by the demands of the literary theory of his day, and others went a step further and read Vondel on the basis of their own ideas.

\footnotetext{
${ }^{11}$ Smit, Van Pascha tot Noah, II, p. 176; Smit, 'Nieuwe Vondel-literatuur'.
} 
In one sense in particular this was certainly no loss. As Smit saw it, the modern reader needed to step out of his own world. He ought to be interested in Vondel in the light of the poet's own time, and if that specific interest was lacking then unfortunately there was nothing to be done. That it was lacking became all too clear. Vondel had hardly any readers and his plays were performed only rarely. Even when they were, the directors who took them on were not about to let Smit lay down the law. Far from it. In 1979, for instance, Hans Croiset produced a Lucifer that omitted the final chorus, in which insight is offered into the salvation of mankind by Christ. Dramatist Guus Rekers made Lucifer into a character corresponding to 'l'homme révolté as described by Camus. It was an impressive and much praised production, but Vondel would have rejected any such interpretation. ${ }^{12}$

In academic discourse this kind of modern approach to Vondel was first advocated by Ernst van Alphen in a chapter in his book Bang voor schennis (Fearful of Desecration, 1987) in which he uses Vondel's Lucifer to demonstrate how the convention of dramatic unity causes the reader to smooth away contradictions and problems in a text. One such contradiction in his view is the clash between the social code according to which the angels are entirely right to stage a revolt and the theological code according to which they should submit to God's commands as a matter of course. The fall of the angels is therefore both justified and unjustified, and it is up to the reader to choose which code to follow. He should do so irrespective of what Vondel himself thought. Van Alphen assumes the poet favours the theological reading, so there is a suggestion here that the reader can stand in opposition to what an author explicitly lays before him. Such opposition was manifested in the feminist reading of Vondel's theatrical works, for example, in which criticism was made of his one-sided view of women as martyrs, temptresses, and obedient wives - criticism that, as we have seen, arose even in the seventeenth century. ${ }^{13}$

Frans-Willem Korsten, in his study Vondel belicht: Voorstellingen van soevereiniteit (2006, translated in 2009 as Sovereignty as Inviolability: Vondel's Theatrical Explorations in the Dutch Republic), went a step further. He investigates the concept of sovereignty in Vondel's theatrical works and argues that according to Vondel the political system of law

${ }^{12}$ See Guus Rekers, 'Vondel in het perspectief van "L'homme révolté"; of Hoe kun je de onspeelbare Lucifer laten werken?' (1981).

${ }^{13}$ Schenkeveld-van der Dussen, Vondel en het vrouwelijk dier. 
cannot be founded on the almighty God, who imposes a system of law of his own, but that we should instead look to the value of the natural order. Smit's 'meaningfulness of God's rule' is in Korsten's view not the statement of a conclusion but on the contrary a position that comes up for debate and is ultimately rejected. The historical figure of Vondel, a convinced Christian who bowed down before the authority of God as revealed to him in the Bible, is thereby sidelined altogether. Whatever Vondel may assert in the various prefaces to his tragedies about the way in which he has read the Bible and what his characters are intended to represent, Korsten dismisses it all as a series of rhetorical constructs to which he pays no further heed. In his book he rightly objects to a onesided reading of Vondel as an author who does not ask questions but instead offers certainties, but he himself gives a no less one-sided reading, based on what he as a modern reader wishes to see. His book expresses no opposition to the author; as a person he is simply put to one side. There is no further debate with him. The reader has taken command.

In my position as a philologist of the old school I have every respect for deconstructionist innovation as a fascinating, indeed perhaps necessary heuristic method. Nevertheless, readings that arise from a concentration on detail, never addressing the fact that the work as a whole contains signals that clearly point in a different direction, I regard as an incorrect way of dealing with the past.

With Korsten the new paradigm, in which the reader is the central figure, is taken all the way to its logical conclusion. The many reviews ranged from admiring to negative. It remains to be seen how the study of Vondel will develop from this point on. 